Jurnal Info Kesehatan

Vol 16, No.1, Juni 2018, pp. 32-43

P-ISSN 0216-504X, E-ISSN 2620-536X

Journal DOI: https://doi.org/10.31965/infokes

Website: http://jurnal.poltekeskupang.ac.id/index.php/infokes

R E S E A R C H

Open Access

\title{
Hubungan Tingkat Kejadian Karies Gigi Dengan Status Gizi Anak Usia 6 -7 Tahun Di SD Inpres Kaniti Kecamatan Kupang Tengah Kabupaten Kupang
}

\author{
Ferdinan Fankari \\ ffankari22@gmail.com
}

Jurusan Keperawatan Gigi, Poltekkes Kemenkes Kupang

\begin{abstract}
Abstrak
Karies gigi merupakan masalah kesehatan gigi dan mulut pada sebagian besar penduduk Indonesia. Karies gigi paling banyak menyerang anak-anak. Karies yang terjadi pada anakanak sering tidak dirawat atau diobati sehingga mengakibatkan sakit gigi. Kondisi ini dapat berdampak pada kesehatan umum anak dimana frekuensi makan akan berkurang sehingga mengakibatkan gangguan pertumbuhan dan perkembangan yang akan mempengaruhi status gizi anak. Masalah gizi disebabkan oleh banyak faktor yang saling terkait baik secara langsung maupun tidak langsung. Secara langsung dipengaruhi oleh penyakit infeksi dan tidak cukupnya asupan gizi secara kuantitas dan kualitas, sedangkan secara tidak langsung dipengaruhi oleh jangkauan dan kualitas pelayanan kesehatan, pola asuh anak yang kurang memadai, kurang baiknya kondisi sanitasi lingkungan serta rendahnya ketahanan pangan di tingkat rumah tangga. Penelitian ini bertujuan untuk mengetahui hubungan tingkat kejadian karies gigi anak dengan status gizi anak usia 6-7 tahun SDI Kaniti Kabupaten Kupang tahun 2016. Pengambilan data dilakukan dengan melakukan pemeriksaan gigi dan pengukuran tinggi badan dan berat badan. Tingkat kejadian karies gigi anak usia 6-7 tahun SDI Kaniti Kabupaten Kupang tahun 2016 pada kategori tinggi (30,76\%) dan sangat tinggi (37,17\%) dengan rata-rata 3- 6 gigi berlubang dan Status gizi anak usia 6-7 tahun SDI Kaniti Kabupaten Kupang tahun 2016 pada kategori gemuk (26.92\%) dan normal (67.94\%), sehingga Tidak ada hubungan tingkat kejadian karies gigi terhadap status gizi anak usia 6-7 tahun SDN Kaniti Kabupaten Kupang tahun 2016 karena anak yang memiliki tingkat kejadian karies tinggi dan sangat tinggi memilki status gizi gemuk dan normal. Disarankan untuk dilakukan penelitian lanjutan tentang faktor-faktor yang mempengaruhi tingginya tingkat kejadian karies gigi pada anak usia 6-7 tahun di SDN Kaniti Kecamatan Kupang Tengah Kabupaten Kupang.
\end{abstract}

Kata kunci: Karies gigi, Status gizi anak, Tingkat kejadian 


\title{
Relationship Between the Level of Dental Caries Events with Children's Nutritional Status Aged 6-7 Years in SD Inpres Kaniti Subdistrict, Kupang Tengah District, Kupang Regency
}

\begin{abstract}
Dental caries is a dental and oral health problem for the majority of the Indonesian population. Dental caries affects most children. Caries that occur in children is often not treated or treated, resulting in toothache. This condition can have an impact on the general health of the child where the frequency of eating will decrease, resulting in disruption of growth and development that will affect the nutritional status of the child. Nutritional problems are caused by many factors that are interrelated both directly and indirectly. Directly affected by infectious diseases and insufficient nutrition in quantity and quality, while indirectly influenced by the range and quality of health services, inadequate parenting, poor sanitation conditions and low food security at the household level. This study aims to determine the relationship between the incidence of dental caries in children with the nutritional status of children aged 6-7 years SDI Kaniti Kabupaten Kupang in 2016. Data collection was carried out by performing dental examinations and measuring height and weight. The incidence rate of dental caries aged 6-7 years old SDI Kaniti Kabupaten Kupang in 2016 was in the high category (30.76\%) and very high (37.17\%) with an average 36 cavities and nutritional status of children aged 6- 7 years SDN Kaniti Kabupaten Kupang in 2016 was categorized as obese (26.92\%) and normal (67.94\%), so there was no correlation between the incidence of dental caries on the nutritional status of 6-7-year-olds in Kaniti Regency Kupang in 2016 because children who had high and very high caries incidence has fat and normal nutritional status. It is recommended to conduct further research on the factors that influence the high incidence of dental caries in children aged 6-7 years at SDN Kaniti, Kupang Tengah District, Kupang Regency.

Keywords: Dental Caries, Nutritional Status of Children, The Incidence Rate
\end{abstract}

\footnotetext{
* Correspondence: ffankari22@ gmail.com

Present Address: Departement of Dental Health, Poltekkes Kemenkes Kupang, Kupang City, Indonesia

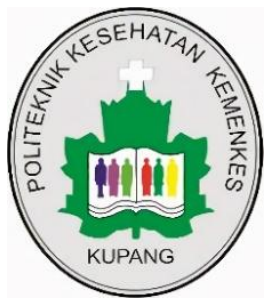

(C)The Author(s) 2018. This article is distributed under the terms of the Creative Commons Attribution $\quad 4.0 \quad$ International License (http://creativecommons.org/licenses/by/4.0/), which permits unrestricted use, distribution, and reproduction in any medium, provided you give appropriate credit to the original author(s) and the source, provide a link to the Creative Commons license, and indicate if changes were made. The Creative Commons Public Domain Dedication waiver (http://creativecommons.org/publicdomain/zero/1.0/) applies to the data made available in this article, unless otherwise stated.
} 


\section{PENDAHULUAN}

Kesehatan gigi merupakan bagian integral dari kesehatan umum. Gigi merupakan organ tubuh yang berperan penting untuk pencernaan makanan bagi kesehatan tubuh. Peranan rongga mulut sangat besar bagi kesehatan dan kesejahteraan manusia. Secara umum, seseorang dikatakan sehat bukan hanya karena tubuhnya yang sehat melainkan juga rongga mulut dan giginya. Orang yang memiliki rongga mulut yang sehat dalam hal ini gigi yang sehat, dapat berkomunikasi secara efektif, menikmati berbagai jenis makanan dan meningkatkan rasa percaya diri. Sebaliknya memiliki gigi berlubang dapat berpengaruh pada keterbatasan fungsi, pengunyahan, fungsi bicara dan menimbulkan rasa sakit yang menyebabkan terganggunya waktu bekerja atau sekolah (Pintauli dan Hamada, 2010).

Karies gigi merupakan masalah kesehatan gigi dan mulut pada sebagian besar penduduk Indonesia. Karies gigi paling banyak menyerang anak-anak. Karies yang terjadi pada anak-anak sering tidak dirawat atau diobati sehingga mengakibatkan sakit gigi. Kondisi ini dapat berdampak pada kesehatan umum anak dimana frekuensi makan akan berkurang sehingga mengakibatkan gangguan pertumbuhan dan perkembangan yang akan mempengaruhi status gizi anak (Siagian, 2008, cit, Kusumawati, 2010). Kelas 1 sekolah dasar dengan kisaran usia dari 6 sampai 7 tahun. Usia 6 tahun merupakan waktu mulai tanggalnya gigi susu dan awal terjadinya erupsi gigi tetap. Gigi incisivus satu rahang atas dan rahang bawah gigi susu mulai tanggal dan diganti dengan erupsinya gigi incisivus tetap. Gigi molar tetap juga tumbuh pada usia ini namun pembentukan benih giginya sudah sejak umur 0 sampai 3 bulan. Usia ini merupakan usia yang rawan karena mulai masuk dalam periode gigi bercampur. Usia ini juga kemampuan pelihara diri khususnya dalam bidang kesehatan gigi dan mulut masih sangat rendah. Pemilihan makan yang tepat untuk mendukung pertumbuhan gigi dan pertumbuhan badan secara keseluruhan juga masih sangat rendah karena masih memilih makanan sesuai seleranya yaitu makanan yang manis, mudah lengket tanpa mempertimbangkan kualitas gizi bagi perkembangan tubuhnya.

Masalah gizi disebabkan oleh banyak faktor yang saling terkait baik secara langsung maupun tidak langsung. Secara langsung dipengaruhi oleh penyakit infeksi dan tidak cukupnya asupan gizi secara kuantitas dan kualitas, sedangkan secara tidak langsung dipengaruhi oleh jangkauan 
dan kualitas pelayanan kesehatan, pola asuh anak yang kurang memadai, kurang baiknya kondisi sanitasi lingkungan serta rendahnya ketahanan pangan di tingkat rumah tangga (Azwar, 2004). Gizi berperan penting dalam pembangunan ekonomi nasional, apabila kekurangan gizi maka berakibat pada rendahnya tingkat produktivitas sumber daya manusia. Anak usia sekolah dasar merupakan generasi penerus tumpuan bangsa sehingga perlu dipersiapkan dengan baik kualitasnya. Anak sekolah sedang mengalami pertumbuhan secara fisik dan mental yang sangat diperlukan guna menunjang kehidupannya dimasa mendatang, guna mendukung keadaan tersebut diatas anak sekolah memerlukan kondisi tubuh yang optimal dan bugar, sehingga memerlukan status gizi yang baik (Bappenas, 2013)

Berdasarkan hasil Riskesdas, 2013, prevalensi sangat kurus menurut indeks masa tubuh pada anak umur 5 sampai 12 tahun paling tinggi di propinsi Nusa Tenggara Timur yaitu 7,8 \%. Angka ini menunjukan bahwa masalah gizi yangsedang dialami pada anak di Propinsi Nusa Tenggara Timur perlu mendapat asupan gizi yang berkualitas juga bebas dari penyakit infeksi yang diderita salah satunya adalah karies gigi. Indeks DMF-T usia $\geqslant 12$ tahun di propinsi Nusa Tenggara Timur yaitu $\mathrm{D}-\mathrm{T}=1,5$ $\mathrm{M}-\mathrm{T}=1,7 \quad \mathrm{~F}-\mathrm{T}=0,04 \quad \mathrm{DMF}-\mathrm{T}=3,2$. Hasil ini menunjukan rata-rata anak usia $\geqslant 12$ tahun mempunyai 3 gigi berkaries. Angka ini masih jauh dari harapan yang ditetapkan oleh WHO (2001) bahwa indeks DMF-T usia $\geqslant 12$ tahun per anak tidak lebih dari 1 gigi. Berdasarkan latar belakang tersebut, maka penulis tertarik ingin melakukan penelitian dengan judul "Hubungan Tingkat Kejadian Karies Terhadap Status Gizi Anak usia 6-7 Tahun SDI Kaniti Kecamatan Kupang Tengah Kabupaten Kupang.

\section{METODE PENELITIAN}

Metode penelitian yang digunakan dalam penelitian ini adalah metode penelitian penjelasan (explanatoryresearch method) yaitu penelitian yang bersifat menjelaskan variabel-variabel penelitian yang dilakukan . Teknik pengumpulam data yang digunakandalam penelitian ini adalah dengan melakukan pemeriksaan karies gigi dan pengukuran tinggi badan dan berat badan. Setelah data terkumpul selanjutnya dilakukan analisa metode kuantitatif untuk mengetahui hubungan tingkat kejadian karies terhadap status gizi anak. Lokasi penelitian SD Inpres Kaniti, Desa Penfui Timur, Kecamatan Kupang Tengah 
Kabupaten Kupang. Populasi adalah seluruh siswa SD Inpres Kaniti, Desa Penfui Timur, Kecamatan Kupang Tengah Kabupaten Kupang sebanyak 176 anak. Teknik pengambilan sampel yang digunakan dalam penelitian ini adalah purposive sample yaitu hanya anak yang berumur 6 - 7 tahun pada SD Inpres Kaniti yang akan jadi responden. Besarnya sample dalam penelitian ini adalah sebanyak 88 anak.

\section{HASIL DAN PEMBAHASAN}

Sekolah Dasar Inpres Kaniti merupakan salah satu Sekolah yang sering di jadikan sebagai lahan praktek mahasiswa Jurusan Keperawatan Gigi Poltekkes Kemenkes Kupang. Jumlah siswa di SDN Kaniti Kecamatan Kupang Tengah Kabupaten
Kupang saat ini berjumlah 279 dengan rincian laki-laki 115 dan perempuan 164 yang tersebar di kelas satu sampai kelas enam.

Penelitian ini dilakukan pada anak Sekolah Dasar Negeri Kaniti yang berumur 6 - 7 tahun sebanyak 78 anak. Penelitian dilakukan dengan 2 tahap yaitu : pada tahap pertama dilakukan pemeriksaan gigi pada semua responden untuk melihat karies gigi dengan munggunakan diagnostik set dan dicatat dalam kartu status. Tahap kedua dilakukan pengukuran status gizi yaitu dengan mengukur tinggi badan dan penimbangan berat badan.

Berdasarkan penelitian yang dilakukan pada anak usia 6-7 tahun di SDN Kaniti, diperoleh hasil sebagai berikut :

Tabel 1.Distribusi frekuensi kejadian karies gigi menurut umur dan jenis kelamin

\begin{tabular}{|c|c|c|c|c|c|c|c|c|c|c|}
\hline \multirow{3}{*}{ Variabel } & \multicolumn{10}{|c|}{ Karies } \\
\hline & \multicolumn{2}{|c|}{$\begin{array}{l}\text { Sangat } \\
\text { Rendah }(0,0- \\
1,1)\end{array}$} & \multicolumn{2}{|c|}{$\begin{array}{l}\text { Rendah } \\
(1,2-2,6)\end{array}$} & \multicolumn{2}{|c|}{$\begin{array}{c}\text { Sedang } \\
(2,7-4,4)\end{array}$} & \multicolumn{2}{|c|}{$\begin{array}{c}\text { Tinggi } \\
(4,5-6,5)\end{array}$} & \multicolumn{2}{|c|}{$\begin{array}{c}\text { Sangat } \\
\text { tinggi } \\
(>6,6)\end{array}$} \\
\hline & $\mathbf{n}$ & $\%$ & $\mathbf{n}$ & $\%$ & $\mathbf{n}$ & $\%$ & $\mathbf{n}$ & $\%$ & n & $\%$ \\
\hline \multicolumn{11}{|l|}{ umur } \\
\hline 6 thn & 5 & 6.41 & 3 & 3.84 & 0 & 0 & 6 & 7.69 & 11 & 14.1 \\
\hline 7 thn & 6 & 7.69 & 5 & 6.41 & 6 & 7.69 & 18 & 13.07 & 18 & !3.07 \\
\hline & 11 & & 8 & & 6 & & 24 & & 29 & \\
\hline
\end{tabular}

Tabel 1. Hasil Menunjukkan bahwa karies gigi pada anak usia 6 tahun dengan tingkat kejadian karies sangat rendah sebanyak $6.41 \%$, karies rendah $3.84 \%$, karies rendah $0 \%$, karies tinggi $7.69 \%$ dan karies sangat tinggi adalah sebesar $14.10 \%$. 
Fankari, F. (2018). Hubungan Tingkat Kejadian Karies Gigi Dengan Status Gizi Anak Usia 6 -7 Tahun Di SD Inpres Kaniti Kecamatan Kupang Tengah Kabupaten Kupang. JURNAL INFO

Sedangkan karies gigi pada anak usia 7 tahun dengan tingkat kejadian karies sangat rendah sebanyak $7.69 \%$, karies rendah $6.41 \%$, karies sedang $7.69 \%$, karies tinggi $23 \%$ dan sangat tinggi sebanyak 23.07

$\%$.

Tabel 2. Distribusi Frekuensi kejadian karis menurut jenis kelamin

\begin{tabular}{|c|c|c|c|c|c|c|c|c|c|c|}
\hline \multirow[t]{3}{*}{ Variabel } & \multicolumn{10}{|c|}{ Karies } \\
\hline & \multicolumn{2}{|c|}{$\begin{array}{l}\text { Sangat } \\
\text { Rendah } \\
(0,0-1,1)\end{array}$} & \multicolumn{2}{|c|}{$\begin{array}{l}\text { Rendah } \\
(1,2-2,6)\end{array}$} & \multicolumn{2}{|c|}{$\begin{array}{c}\text { Sedang } \\
(2,7-4,4)\end{array}$} & \multicolumn{2}{|c|}{$\begin{array}{c}\text { Tinggi } \\
(4,5-6,5)\end{array}$} & \multicolumn{2}{|c|}{$\begin{array}{l}\text { Sangat } \\
\text { tinggi } \\
(>6,6)\end{array}$} \\
\hline & $\mathrm{n}$ & $\%$ & $\mathrm{n}$ & $\%$ & $\mathrm{n}$ & $\%$ & $\mathrm{n}$ & $\%$ & $\mathrm{n}$ & $\%$ \\
\hline Jenis & 7 & 8.97 & 3 & 3.94 & 0 & 0 & 12 & 15.38 & 14 & 17.94 \\
\hline \multicolumn{11}{|l|}{ kelamin } \\
\hline \multicolumn{11}{|l|}{ Laki-laki } \\
\hline Perempuan & 2 & 2.56 & 5 & 6.41 & 6 & 7.69 & 12 & 15.38 & 17 & 21.79 \\
\hline Jumlah & 9 & & 8 & & 6 & & 24 & & 31 & \\
\hline
\end{tabular}

Tabel 2. Hasil Menunjukkan bahwa karies gigi pada anak usia laki-laki dengan tingkat kejadian karies sangat rendah sebanyak $8.97 \%$, karies rendah $3.94 \%$, karies sedang $0 \%$, karies tinggi $15.38 \%$ dan karies sangat tinggi sebesar $17.94 \%$.
Sedangkan karies gigi pada anak perempuan dengan tingkat kejadian karies sangat rendah sebanyak $2.56 \%$, karies rendah $6.41 \%$, karies sedang $7.69 \%$, karies tinggi $15.38 \%$ dan sangat tinggi sebanyak 21.79 $\%$.

Tabel 3. Distribusi frekuensi kejadian karies anak SDN Kaniti

\begin{tabular}{|c|c|c|c|c|}
\hline \multicolumn{5}{|c|}{ Karies Gigi } \\
\hline $\begin{array}{c}\text { Sangat } \\
\text { Rendah } \\
(0,0-1,1)\end{array}$ & $\begin{array}{l}\text { Rendah } \\
(1,2-2,6)\end{array}$ & $\begin{array}{l}\text { Sedang } \\
(2,7-4,4)\end{array}$ & $\begin{array}{c}\text { Tinggi } \\
(4,5-6,5)\end{array}$ & $\begin{array}{c}\text { Sangat tinggi } \\
(>6,6)\end{array}$ \\
\hline$\%$ & $\%$ & $\%$ & $\mathrm{n}$ & $\%$ \\
\hline $11 \quad 14.10$ & 10.25 & 7.69 & 30.76 & 37.17 \\
\hline
\end{tabular}


Tabel 3. Hasil Menunjukkan bahwa rendah $10.25 \%$, tinggi $30.76 \%$, sangat karies gigi pada anak usia $6-7$ tahun di SDN tinggi $30.76 \%$. Kaniti adalah sangat rendah $14.10 \%$,

Tabel 4. Distribusi Frekuensi Status gizi umur

\begin{tabular}{|c|c|c|c|c|c|c|}
\hline \multirow[t]{5}{*}{ Variabel } & \multicolumn{6}{|c|}{ Status Gizi anak (BB/TB) } \\
\hline & \multirow{3}{*}{\multicolumn{2}{|c|}{$\begin{array}{c}\text { Gemuk } \\
\text { Berada diatas garis } \\
\text { SD + } 2 \text { sampai SD + } 3\end{array}$}} & \multicolumn{2}{|c|}{ Normal } & \multicolumn{2}{|c|}{ Kurus } \\
\hline & & & \multicolumn{2}{|c|}{ Berada digaris SD } & \multicolumn{2}{|c|}{ Berada dibawah } \\
\hline & & & \multicolumn{2}{|c|}{ + 2 sampai SD - 2} & \multicolumn{2}{|c|}{$\begin{array}{c}\text { garis SD-2 } \\
\text { sampai SD - } 3\end{array}$} \\
\hline & $\mathrm{n}$ & $\%$ & $\mathrm{n}$ & $\%$ & $\mathrm{n}$ & $\%$ \\
\hline Umur & 10 & 12.82 & 15 & 19.23 & 0 & 0 \\
\hline \multicolumn{7}{|l|}{6 thn } \\
\hline Umur & 11 & 14.10 & 38 & 48.71 & 4 & 5.12 \\
\hline \multicolumn{7}{|l|}{7 thn } \\
\hline & 21 & & 53 & & 4 & 78 \\
\hline
\end{tabular}

Tabel 4. Hasil Menunjukkan bahwa status gizi pada anak usia 6 tahun dengan kriteria gemuk $12.82 \%$, normal $19.23 \%$ dan kurus 0 \%. Sedangkan status gizi pada

Tabel 5. Distribusi Frekuensi Status gizi Jenis Kelamin

\begin{tabular}{|c|c|c|c|c|c|c|}
\hline \multirow[t]{6}{*}{ Variabel } & \multicolumn{6}{|c|}{ Status Gizi anak (BB/TB) } \\
\hline & \multirow{4}{*}{\multicolumn{2}{|c|}{$\begin{array}{c}\text { Gemuk } \\
\text { Berada diatas garis } \\
\text { SD + } 2 \text { sampai SD + } \\
3\end{array}$}} & \multirow{4}{*}{\multicolumn{2}{|c|}{$\begin{array}{c}\text { Normal } \\
\text { Berada digaris SD } \\
+2 \text { sampai SD - } 2\end{array}$}} & \multirow{4}{*}{\multicolumn{2}{|c|}{$\begin{array}{c}\text { Kurus } \\
\text { Berada dibawah } \\
\text { garis SD-2 } \\
\text { sampai SD - } 3\end{array}$}} \\
\hline & & & & & & \\
\hline & & & & & & \\
\hline & & & & & & \\
\hline & $\mathrm{n}$ & $\%$ & $\mathrm{n}$ & $\%$ & $\mathrm{n}$ & $\%$ \\
\hline Laki-laki & 8 & 10.25 & 30 & 38.46 & 4 & 5.12 \\
\hline Perempuan & 12 & 15.38 & 24 & 30.76 & 0 & 0 \\
\hline Ttl & 20 & & 54 & & 4 & 78 \\
\hline
\end{tabular}


Tabel 5. Hasil Menunjukkan bahwa status gizi pada anak laki-laki dengan kriteria gemuk $10.25 \%$, normal $38.46 \%$ dan kurus $5.12 \%$. Sedangkan status gizi pada anak perempuan dengan dengan kriteria gemuk $15.38 \%$, normal $30.76 \%$ dan kurus 0 $\%$.

Tabel 6. Distribusi Frekuensi Status gizi anak SDN Kaniti

\begin{tabular}{|c|c|c|}
\hline \multicolumn{3}{|c|}{ Status Gizi (BB/TB) } \\
\hline Gemuk & Normal & Kurus \\
\hline Berada & Berada & Berada dibawah \\
\hline diatas garis & digaris SD & garis SD-2 \\
\hline $\mathrm{SD}+2$ & + 2 sampai & sampai SD - 3 \\
\hline sampai SD & $S D-2$ & \\
\hline \multicolumn{3}{|l|}{+3} \\
\hline$\%$ & $\%$ & $\%$ \\
\hline 26.92 & 67.94 & 5.12 \\
\hline
\end{tabular}

Tabel 6. Hasil Menunjukkan bahwa status gizi pada SD Negeri Kaniti adalah dengan kriteria gemuk $26.92 \%$, normal $67.94 \%$ dan kurus $5.12 \%$.

Tabel. 7. Hubungan tingkat kejadian karies gigi dengan status gizi Anak Usia $6-7$ tahun Di SDN Kaniti

\begin{tabular}{cccc}
\hline KARIES & \multicolumn{3}{c}{ STATUS } \\
GIGI & Gemuk & Normal & Kurus \\
& Berada & Berada & Berada \\
& diatas & digaris & dibawah \\
& garis SD & SD +2 & garis \\
\hline
\end{tabular}

\begin{tabular}{ccccccc}
\hline & +2 & sampai & \multicolumn{2}{c}{ SD-2 } \\
& sampai & SD - 2 & \multicolumn{2}{c}{ sampai } \\
& SD + 3 & & & \multicolumn{2}{c}{ SD - 3 } \\
\hline & $\mathrm{n}$ & $\%$ & $\mathrm{n}$ & $\%$ & $\mathrm{n}$ & $\%$ \\
\hline Sangat & 4 & 5.12 & 7 & 8.97 & 0 & 0 \\
Rendah & & & & & & \\
$(0,0-1,1$ & & & & & & \\
\hline Rendah & 2 & 2.56 & 6 & 7.69 & 0 & 0
\end{tabular}

$(1,2-$

2,6)

\begin{tabular}{ccccccc} 
Sedang & 1 & 1.28 & 5 & 6.41 & 0 & 0 \\
$(2,7-$ & & & & & & \\
$4,4)$ & & & & & & \\
\hline Tinggi & 2 & 2.56 & 20 & 25.64 & 2 & 2.56 \\
$(4,5-$ & & & & & & \\
$6,5)$ & & & & & &
\end{tabular}

$\begin{array}{lllllll}\text { Sangat } & 11 & 14.1 & 17 & 21.79 & 1 & 1.28\end{array}$

tinggi

$(>6,6)$

\begin{tabular}{lllll}
\hline Total & 20 & 55 & 3 & 78
\end{tabular}

Tabel 7. Hasil menunjukkan bahwa anak dengan karies sangat rendah dengan status gizi gemuk sebanyak $5.12 \%$, status gizi normal $8.97 \%$ dan kurus 0 \%, anak dengan karies rendah dengan status gizi gemuk $2.56 \%$, normal $7.69 \%$, $0 \%$, anak dengan karies sedang dengan status gizi gemuk $1.28 \%$, normal $6.41 \%$, kurus $0 \%$, anak dengan karies tinggi dengan status gizi gemuk $2.56 \%$, normal $25.64 \%$, kurus 2.56 $\%$, anak dengan karies sangat tinggi dengan 
status gizi gemuk 14,1 \%, normal 21,79\% dan status kurus adalah $1.83 \%$.

\section{PEMBAHASAN}

Hasil penelitian pada tabel 1 . tentang tingkat kejadian karies anak SDN kaniti menurut umur, hasil menunjukkan bahwa 7,69 \% anak usia 6 tahun memiliki karies tinggi dan 14,1 \% memiliki karies sangat tinggi. Sedangkan anak usia 7 tahun 23,07 \% memiliki karies tinggi dan sangat tinggi 23,07 \%. Hasil ini dapat disebabkan karena secara epidemiologis menunujukkan terjadi peningkatan prevalensi karies sejalan dengan bertambahnya umur. Gigi yang paling akhir erupsi lebih rentan terhadap karies. Kerentatanan ini meningkat karena sulitnya membersihkan gigi yang sedang erupsi sampai gigi tersebut mencapai dataran oklusal dan beroklusi dengan gigi antagonisnya. Anak mempunyai resiko karies yang paling tinggi ketika gigi mereka baru mulai erupsi.

Selanjutnya pada tabel 2 . yang memperlihatkan hasil tingkat kejadian keries gigi anak SDN Kaniti menurut jenis kelamin. Hasil Menunujukkan bahwa 15,38 \% anak laki-laki memiliki karies tinggi dan 17,94 \% memiliki karies sangat tinggi. Sedangkan anak perempuan yang memiliki karies tinggi adalah $15.38 \%$ dan $21,79 \%$ memiliki karies tinggi. Hal ini disebabkan karena anak laki-laki memilki keberanian untuk memeriksaakan gigi dan ada kecenderungan kebiasaan jajan disekolah dimana anak perempuan lebih banyak jajanan dibanding anak laki-laki. Pada tabel 3. memperlihatkan tingkat kejadian karies anak SDN Kaniti hasil menunjukkan bahwa 30,76 \% anak memiliki karies tinggi dan $37,17 \%$ anak memiliki karies sangat tinggi. Hal ini disebabkan karena anak-anak pada usia 6-7 tahun belum memiliki kebiasaan menyikat gigi yang baik dan benar.

Hasil penelitian pada tabel 4. hasil menunjukkan bahwa $12.82 \%$ anak usia 6 tahun memiliki status gigi gemuk, 19,23\% status gizi normal dan kurs $0 \%$. Sedangkan anak usia 7 tahun dengan status gizi gemuk $14.10 \%$, normal $48.71 \%$, status kurus 5.12 \%. Hasil ini disebabkan karena semakin bertambah usia kebutuhan akan zat gizi makin meningkat sehingga sehingga semakin bertambah usia semakin baik status gizi anak. Selanjutnya pada tabel 5 yang memperlihatkan hasil status gizi menurut jenis kelamin menunjukkan bahwa anak laki-laki dengan status gizi gemuk $12.82 \%$, normal 19,23 \% dan kurus $5.12 \%$, sedangkan anak perempuan dengan status gemuk 15,38 \%, normal $30.76 \%$ dan kurus 0 \%. Hal ini disebabkan karena kebiasaan makan lebih banyak anak perempuan dibanding anak laki-laki. Selanjutnya pada tabel 6. memperlihatkan status gizi anak SDN Kaniti menunjukkan bahwa status gizi 
pada SD Negeri Kaniti dengan kriteria gemuk $26.92 \%$, normal $67.94 \%$ dan kurus $5.12 \%$.

Hasil penelitian tabel memperlihatkan hubungan tingkat kejadian karies gigi dengan status gizi anak usia 6-7 tahun di SDN Kaniti, hasil penelitian menunjukkan bahwa tidak ada hubungan antara tingkat kejadian karies dengan status gizi anak usia 6-7 tahun di SDN Kaniti Kecamatan Kupang Tengah Kabupaten Kupang. Hasil menunjukkan bahwa tingkat kejadian karies pada anak SDI Kaniti termasuk kategori tinggi dan sangat tinggi sedangkan status gizi kategori termasuk kriteria normal dan gemuk dan obesitas juga tinggi. Bahwa anak yang memiliki karies sedang (2.7 - 4,4 gigi karies) memiliki status gizi gemuk $1.28 \%$, normal $6.41 \%$ dan status gizi kurus $0 \%$, anak dengan karies tinggi (4.5 - 6,5 berkaries) memiliki status gizi gemuk 2,56 \% dan status gizi normal sebesar $25,64 \%$, hanya $2,56 \%$ anak yang memiliki status gizi kurus dan karies sangat tinggi (>6 gigi berkaries) memiliki status gizi gemuk $14.1 \%$, status gizi normal $21.79 \%$ dan status gizi kurus 1,28 \%. Hasil ini disebabkan karena anak pada usia 6-7 tahun memiliki kecenderungan yang tinggi untuk makan -makanan selain nasi dan sayauran yaitu kebiasaan jajanan. Anak usia 6-7 tahun juga belum memilki kebiasaan menyikat gigi yang baik dan benar. Rongga mulut yang jika tidak dibersihkan secara teratur akan menyebabkan sisa-sisa makanan yang tertinggal di rongga mulut mengendap didalam mulut dan akan menjadi plak. Semakin tinggi anak mengkonsumsi makanan kariogenik maka akan semakin tinggi indek karies giginya. Jenis makan yang sering dikonsumsi dapat mempengaruhi keparahan karies gigi. Salah satu makanan yang dapat menyebabkan karies gigi yaitu makanan banyak mengandung gula dan sukrosa. Sukrosa mempunyai kemampuan yang lebih efisien terhadap pertumbuhan mikroorganisme dan metabolisme dengan cepat untuk menghasilkan zat-zat asam. Makanan yang menempel pada permukaan gigi jika dibiarkan akan menghasilkan zat azam lebih banyak, sehingga mempertinggi resiko terkena karies gigi. Hal ini sama dengan hasil penelitian Asmawati 2007 yang dilakukan pada anak SDN 060935 Medan, bahwa sebagian besar anak sekolah sangat suka makanan yang manis, lunak, melekat (bersifat kariogenik) dan makan yang bentuknya menarik. Meningkatnya konsumsi makanan-makanan tersebut kebanyakn mengandung gula, maka sering sulit bagi anak untuk menghindari konsumsi 
gula yang banyak. Hasil ini menggambarkan kemampuan ekonomi orang tua siswa dengan daya beli yang cukup baik biasanya konsumsi gula yang cukup tinggi, sehingga resiko terjadinya karies cukup besar. Selain itu biasanya pada kelompok ekonomi menengah lebih mementingkan masalah yang berbau konsumtif sehingga persoalan kesehatan gigi dan mulut belum menjadi prioritas. Selain itu perilaku menyikat gigi juga menjadi salah satu faktor tingginya karies gigi. Dari hasil wawancara yang dilakukan peneliti kepada responden anakanak belum memiliki kebiasan menyikat gigi yang baik dan benar. Selain belum memiliki kebiasan menyikat gigi yang baik dan benar, anak-anak juga belum melakukan sikat gigi pada waktu yang tepat yaitu setelh makan pagi dan sebelum tidur malam. Menurut Mohammadi (2012) bahwa pola makan sangat mepengaruhi pola tumbuh kembang anak karena kebutuhan makanannya terutama untuk memenuhi kebutuhan zat zat gizi dalam tubuhnya. Selain pola makan, ditambah dengan keadaan ekonomi keluarga yang dapat mempengaruhi asupan nutrisi anak. Menurut Soehardjo menunjukkan bahwa faktor sosial ekonomi merupakan faktor yang mengakibatkan kekurangan gizi atau malnutrisi karena sangat mepengaruhi penyediaan pangan sehari-sehari. Dengan demikian walaupun anak memiliki karies dengan tingkat kejadian tinggi tetap anak memilki status gizi normal.

\section{KESIMPULAN}

Berdasarkan hasil penelitian dan pembahasan dapat disimpulkan bahwa Tingkat kejadian karies gigi anak usia 6-7 tahun SDI Kaniti Kabupaten Kupang tahun 2016 pada kategori tinggi (30,76 \%) dan sangat tinggi (37,17 \%) dengan rata-rata 36 gigi berlubang. Untuk Status gizi anak usia 6-7 tahun SDI Kaniti Kabupaten Kupang tahun 2016 pada kategori gemuk (26.92\%) dan normal (67.94 \%). Sehingga tidak ada hubungan tingkat kejadian karies gigi terhadap status gizi anak usia 6-7 tahun SDN Kaniti Kabupaten Kupang tahun 2016 karena anak yang memiliki tingkat kejadian karies tinggi dan sangat tinggi memilki status gizi gemuk dan normal.

Disarankan untuk penelitian lanjutan tentang faktor-faktor yang mempengaruhi tingginya tingkat kejadian karies gigi pada anak usia 6-7 tahun di SDN Kaniti Kecamatan Kupang Tengah Kabupaten Kupang. Perlu dilakukan program promotif kesehatan gigi melalui penyuluhan kesehatan gigi tentang makanan yang menyehatkan gigi dan cara menyikat gigi yang baik dan benar dan perlu dilakukan penutupan dengan bahan fissure sealant bagi fissure yang dalam. 
Fankari, F. (2018). Hubungan Tingkat Kejadian Karies Gigi Dengan Status Gizi Anak Usia 6 -7

Tahun Di SD Inpres Kaniti Kecamatan Kupang Tengah Kabupaten Kupang. JURNAL INFO

\section{REFERENCES}

Arikunto. (2010). Teknik pengambilan sampel, Alfabeta, Jakarta.

Angela, A. (2005). Pencegahan Primer Pada Anak Yang Berisiko Karies Tinggi, Maj. Ked. Gigi. (Dent. J.), Vol. 38. No. 3 .

Anggraeni Z.R .(2013). Kualitas Kesehatan Gigi Masih Rendah”.

Astuti T. (2007). Kesehatan Gigi 90 Persen Anak Indonesia Buruk ”.

Asmawati. (2007). Analisis Hubungan Karies Gigi dan Status Gizi Anak SD Athira, SDN I Bawakaraeng, SDN 3 Bangkala, FKG, UNHAS Makasar, Dentofasial, vol 6,no.2, Oktober 2007.

Budsuari. (2010). Hubungan Pola Makan dan kebiasaan menyikat gigi dengan karies gigi, bulletin penelitian system kesehatan Vol 13 No. 1.

Dwiatmoko, S dan Kiswantoro. (2012). Keadaan Gizi dan Karies Gigi anak 2-5 tahun diKecamatan
Sumbersaru Jember, Jurnal Edu Health, Vol 2 no 2 Juli 2012.

Herijulianti, E, Indriani,T.S, Artini,S. (2002).

Pendidikan Kesehatan Gigi. EGC. Jakarta.

Marfanah S. (2001). Dasar-Dasar Pengetahuan

Mengenai

Permasalahan Kesehatan Gigi,

Sipress. Yogyakarta.

Nova. (2010). Rawat Gigi Sedini Mungkin.

http://www.pdgi-

online.com/v2/index.php (diakses

4 April 2016).

Lubis. S.L.A. (2001). Fluor dalam Pencegahan Karies Gigi, USU e-Repository.

Situmorang, N. (2004). Dampak Karies Gigi dan Penyakit Periodontal Terhadap Kualitas Hidup, Disertasi Program Pascasarjana Ilmu Kesehatan Masyarakat. Universitas Indonesia. Jakarta.

Soehardjo. (2003). Berbagai Cara Pendidikan Gizi, Jakarta, bina aksara.

Pratiwi D. (2007). Gigi Sehat Merawat Gigi Sehari - hari. Kompas. Jakarta.

Ready to submit your research? Choose INFOKES and benefit from:

- fast, convenient online submission

- thorough peer review by experienced researchers in your field

- $\quad$ rapid publication on acceptance

- $\quad$ support for research data

- Open Access which fosters wider collaboration and increased citations

- maximum visibility for your research

At Health Polytechnic of Kupang, research is always in progress.

Learn more http://jurnal.poltekkekupang.ac.id/index.php/infokes 